\title{
SISTEM PENDUKUNG KEPUTUSAN PEMBERIAN BEASISWA BIDIKMISI MENGGUNAKAN METODE SAW-TOPSIS DI STAH MPU KUTURAN SINGARAJA
}

\author{
I Gede Teguh Heriawan ${ }^{1}$, I Gede Bendesa Subawa ${ }^{2}$ \\ ${ }^{1}$ Prodi IImu Komunikasi, Sekolah Tinggi Agama Hindu Negeri Mpu Kuturan \\ Singaraja, Indonesia \\ 2 Prodi Pendidikan Teknik Informatika, Universitas Pendidikan Ganesha \\ Singaraja, Indonesia \\ e-mail: teguhheriawan@stahnmpukuturan.ac.id ${ }^{1}$, bendesa.subawa@undiksha.ac.id른
}

\begin{abstract}
Abstrak
Penelitian ini bertujuan untuk membuat sebuat sistem pendukung keputusan (SPK) dalam memberikan rekomendasi calon mahasiswa penerima bantuan beasiswa bidikmisi. Studi kasus penelitian ini adalah Sekolah Tinggi Agama Hindu Mpu Kuturan Singaraja. Adapun metode pendukung keputusan yang digunakan adalah kombinasi dari metode SAW (Simple Additive Weighting) dan TOPSIS. Data penelitian yang digunakan adalah 30 calon mahasiswa penerima beasiswa dan dicari 10 orang rekomendasi. Kriteria penilaian yang digunakan adalah penghasilan ayah, penghasilan ibu, tanggungan orang tua, rata-rata nilai raport, prestasi akademik, tempat tinggal, pendidikan ayah, pendidikan ibu, luas tanah dan luas bangunan. Akurasi atau tingkat kemiripan hasil rekomendasi oleh sistem pendukung keputusan terhadap perhitungan manual sebesar $90 \%$.
\end{abstract}

Kata kunci: SPK, Simple Additive Weighting, TOPSIS, Bidikmisi

\begin{abstract}
This research aimed to create a Decision Support System (SPK) in providing recommendations for prospective students receiving Bidikmisi scholarship assistance. The case study of this research was the Sekolah Tinggi Agama Hindu Mpu Kuturan Singaraja. As for the Decision Support method used was a combination of the SAW (Simple Additive Weighting) and TOPSIS method. The research data used were 30 prospective scholarship recipients and sought 10 persons that were recommended. The criteria of assessment that was used were father's income, mother's income, dependents of parents, average values of report card, academic achievement, residence, father's educational background, mother's educational background, surface area and building area. The accuracy or degree of similarity from the results of recommendations by the Decision Support System to manual calculations was $90 \%$.
\end{abstract}

Keywords : SPK, Simple Additive Weighting, TOPSIS, Bidikmisi

\section{PENDAHULUAN}

Melanjutkan pendidikan ke perguruan tinggi setelah menyelesaikan pendidikan di sekolah menengah atas / kejuaruan merupakan cita-cita sebagian besar pelajar. Akan tetapi tidak semua pelajar bisa melanjutkan pendidikan ke perguruan tinggi, salah satu penyebabnya adalah kendala biaya. Tidak dapat dipungkiri untuk melanjutkan pendidikan ke perguruan tinggi dibutuhkan biaya pendidikan yang tidak sedikit, oleh karena itu ketersediaan beasiswa sangat membantu bagi para pelajar tersebut. Salah satu beasiswa yang yang banyak diincar oleh para pelajar adalah beasiswa bidikmisi. Bidikmisi adalah bantuan biaya pendidikan dari pemerintah bagi lulusan Sekolah Menengah Atas (SMA) atau sederajat yang memiliki potensi akademik baik tetapi memiliki keterbatasan ekonomi (Kemenristekdikti, 2019). Pemerintah melalui Direktorat Jurnal Sains dan Teknologi | 116 
Jenderal Pembelajaran dan Kemahasiswaan, Kementerian Riset Teknologi dan Pendidikan Tinggi mulai tahun 2010 meluncurkan Program Bantuan Biaya Pendidikan Bidikmisi yaitu bantuan biaya pendidikan bagi calon mahasiswa tidak mampu secara ekonomi dan memiliki potensi akademik baik untuk menempuh pendidikan di perguruan tinggi pada program studi unggulan sampai lulus tepat waktu.

Sekolah Tinggi Agama Hindu Negeri Mpu Kuturan Singaraja sebagai salah satu perguruan tinggi negeri di Bali melaksanakan pemilihan pemberian beasiswa Bidikmisi bagi mahasiswa baru. Dalam menentukan pemberian beasiswa Bidikmisi mahasiswa di Sekolah Tinggi Agama Hindu Negeri Mpu Kuturan Singaraja, proses yang dilakukan oleh tim penyeleksi berupa tes wawancara serta tes penilian langsung yang dilakukan kepada calon mahasiswa penerima Bidikmisi. Namun saat ini mekanisme penilaian masih bersifat manual, tim seleksi mahasiswa Bidikmisi cenderung dihadapkan pada penilaian yang bersifat subjektif. Untuk menghindari hasil yang kurang objektif maka dibutuhkan sebuah sistem pendukung keputusan yang terkomputerisasi untuk menjadi acuan keputusan yang diambil. Menurut Keen dan Scoot Morton (dalam (Mahendra \& Subawa, 2019) mendefinisikan sistem pendukung keputusan merupakan penggabungan sumber-sumber kecerdasan individu dengan kemampuan komponen untuk memperbaiki kualitas keputusan. Metode pengambilan keputusan ada banyak seperti Analytical Hierarchy Process (AHP), Simple Additive Weighting (SAW), TOPSIS, dan sebagainya. Adapun penelitian yang pernah dilakukan terkait sistem pendukung keputusan adalah sebagi berikut. 1) Sistem pendukung keputusan pemilihan pegawai terbaik di PT. Tirta Mumbul Jaya Abadi menggunakan Metode Simple Additive Weighting (Subawa et al , 2015). 2) Penerapan sistem pendukung keputusan berbasis logika fuzzy ke dalam sistem penentuan kelayakan penerima bidikmisi mampu memberikan solusi dan inovasi baru di bagian kemahasiswaan STMIK Amikom
Yogyakarta. Target luaran dari dari penelitian ini adalah meningkatkan tingkat akurasi penentuan kelayakan bidikimisi (Yaqin, 2016). 3) Sistem pendukung keputusan lomba desa/kelurahan dapat mengatasi kelemahan dan kekurangan dari pelaksanaan lomba sebelumnya. Sistem yang baru ini dapat dilakukan dengan cepat, terbuka dan kompetitif meskipun jumlah data relatif banyak tetapi keakuratan perhitungan serta laporan dapat dicapai semaksimal mungkin (Arfida, 2013).

Metode TOPSIS adalah metode yang didasarkan pada konsep dimana alternatif terpilih yang terbaik tidak hanya memiliki jarak terpendek dari solusi ideal positif, namun juga memiliki jarak terpanjang solusi ideal negative (Kusumadewi et al, 2006). Metode SAW sering dikenal dengan istilah metode penjumlahan terbobot. Konsep dasar metode SAW (Simple Additive Weighting) adalah mencari penjumlahan terbobot dari rating kinerja pada setiap alternatif pada semua atribut. Menurut Iriane \& Wisnubhadra (2013) metode SAW dan TOPSIS konsepnya sederhana, mudah dipahami, komputasinya efisien dan memiliki kemampuan untuk mengukur kinerja relatif dari alternatif-alternatif keputusan dalam bentuk matematis yang sederhana.berdasarkan hal tersebut di atas, pada penelitian ini akan dilakukan pengkombinasian metode SAW dengan TOPSIS dalam menentukan pemberian beasiswa Bidikmisi dengan studi kasus Sekolah Tinggi Agama Hindu Negeri Mpu Kuturan. Penggunaan metode TOPSIS ini dapat digunakan dalam menentukan perangkingan alternatif dengan memperhitungkan solusi ideal dari suatu masalah. Metode TOPSIS akan dipertimbangkan solusi terbaik dan solusi terburuk dari tiap alternatif sehingga alternatif terpilih merupakan solusi yang mampu menghasilkan kombinasi objektif terbaik dan penentuan bobot setiap kriteria. Namun, kurang baik jika digunakan dalam mendapatkan bobot yang memperhitungkan hubungan antara kriteria. Oleh karena itu diperlukan penggabungan dengan metode lain untuk pembobotan seperti metode SAW. Penggunaan metode SAW dikarenakan metode ini mampu 
memberikan penilaian lebih tepat karena didasarkan pada nilai kriteria dari bobot preferensi yang sudah ditentukan serta adanya perhitungan normalisasi matriks sesuai dengan nilai atribut yang memperhatikan antara nilai benefit dan cost dari kriteria yang digunakan. Dengan adanya penggunaan sistem pendukung keputusan diharapkan dapat membantu STAHN Mpu Kuturan dalam menyeleksi penerimaan beasiswa bidik misi yang lebih objektif.

\section{KAJIAN TEORI}

A. Sistem Pendukung Keputusan

Pada dasarnya sistem pendukung keputusan (SPK) merupakan pengembangan lebih lanjut dari sistem informasi managemen terkomputerisasi yang dirancang sedemikian rupa sehingga bersifat interaktif dengan pemakainya (Subawa, et al, 2015). Interaktif dengan tujuan untuk memudahkan integrasi antara berbagai komponen dalam proses pengambilan keputusan seperti prosedur, kebijakan analisis, pengalaman, dan wawasan manager untuk mengambil keputusan dengan baik. Surya (2015) menerangkan Sistem pendikung keputusan merupakan sistem informasi interaktif yang menyediakan informasi, pemodelan, dan pemanipulasian data. Sistem itu digunakan untuk membantu pengambilan keputusan dalam situasi yang semiterstrutur dan situasi yang tidak terstruktur, dimana tak seorang pun tahu secara pasti bagaimana keputusan seharusnya dibuat.

\section{B. Simple Additive Weighting}

Metode SAW dikenal sebagai metode penjumlahan tebobot. Metode ini mengharuskan pembuat keputusan menentukan bobot lagi untuk setiap atribut. Skor total untuk sebuah alternatif diperoleh dengan menjumlahkan seluruh perkalian antara rating (yang dapat dibandingkan lintas atribut) dan bobot tiap atribut. Rating tiap atribut haruslah bebas dimensi yang artinya telah melewati normalisasi terlebih dahulu. Metode SAW mengenal adanya 2 (dua) atribut yaitu kriteria keuntungan (benefit) dan kriteria biaya (Cost). Perbedaan mendasar dari kedua kriteria ini adalah dalam pemilihan kriteria ketika mengambil keputusan.

Adapun langkah-langkah penyelesaian dalam menggunaknnya adalah:

1. Menentukan Alternatif, yaitu $A_{i}$

2. Menetukan kriteria yang akan dijadikan acuan dalam pengambilan keputusan yaitu $\mathrm{C}_{\mathrm{j}}$

3. Memberikan nilai rating kecocokan setiap alternatif pada setiap criteria

4. Menentukan bobot preferensi atau tingkat kepentingan (W) setiap kriteria.

$\mathrm{W}=\left[\begin{array}{lllll}\mathrm{W}_{1} & \mathrm{~W}_{2} & \mathrm{~W}_{3} & \ldots & \mathrm{W}_{\mathrm{j}}\end{array}\right] \quad$ Persamaan 1.

5. Membuat tabel rating kecocokan dari setiap alternatif pada setiap kriteria.

6. Membuat matrik keputusan yang dibentuk dari tabel rating kecocokan dari setiap alternatif pada setiap kriteria. Nilai setiap alternatif $\left(A_{i}\right)$ pada setiap kriteria $\left(C_{j}\right)$ yang sudah ditentukan, dimana $i=1,2, \ldots, m$ dan $j=1,2, \ldots, n$.

$$
X=\left[\begin{array}{ccccc}
x_{11} & x_{12} & x_{13} & \ldots & x_{1 n} \\
x_{21} & x_{22} & x_{23} & \ldots & x_{2 n} \\
x_{31} & x_{32} & x_{33} & \ldots & x_{3 n} \\
\ldots & \ldots & \ldots & \ldots & \ldots \\
x_{m 1} & x_{m 2} & x_{m 3} & \ldots & x_{m n}
\end{array}\right]
$$

7. Melakukan normalisasi matrik keputusan dengan cara menghitung nilai rating kinerja ternormalisasi $\left(r_{i j}\right)$ dari alternatif $A_{i}$ pada kriteria $\mathrm{C}_{\mathrm{j}}$

$r_{i j}=\frac{X_{i j}}{\operatorname{Max}_{i j}}$, jika j adalah atribut

keuntungan (benefit) Persamaan 2

$$
\begin{aligned}
& r_{i j}=\frac{\operatorname{Min} X_{i j}}{X_{i j}}, \text { jika j adalah atribut biaya } \\
& \text { (cost) } \quad \text { Persamaan } 3
\end{aligned}
$$

8. Hasil dari rating kriteria ternormalisasi $\left(r_{i j}\right)$ membentuk matrik ternormalisasi (R).

$$
R=\left[\begin{array}{ccccc}
r_{11} & r_{12} & r_{13} & \ldots & r_{1 n} \\
r_{21} & r_{22} & r_{23} & \ldots & r_{2 n} \\
r_{31} & r_{32} & r_{33} & \ldots & r_{3 n} \\
\ldots & \ldots & \ldots & \ldots & \ldots \\
r_{m 1} & r_{m 2} & r_{m 3} & \ldots & r_{m n}
\end{array}\right]
$$

9. Hasil akhir nilai preferensi $\left(\mathrm{V}_{\mathrm{i}}\right)$ diperoleh dari penjumlahan dari perkalian elemen baris matrik ternormalisasi $(R)$ dengan bobot preferensi (W) yang bersesuaian elemen kolom matrik (W). 


$$
V_{i}=\sum_{j=1}^{n} w_{j} r_{i j} \quad \text { Persamaan } 4
$$

10. Hasil perhitungan nilai $V_{i}$ yang paling besar mengindikasikan bahwa alternatif $A_{i}$ merupakan alternatif yang terbaik.

\section{TOPSIS}

TOPSIS didasarkan pada konsep dimana alternatif terpilih yang terbaik tidak hanya memiliki jarak terpendek dari solusi ideal positif, namun juga memiliki jarak terpanjang dari solusi ideal negative (Kusumadewi et al, 2006) Konsep ini banyak digunakan pada beberapa model MADM untuk menyelesaikan masalah keputusan secara praktis. Hal ini disebabkan konsepnya sederhana dan mudah dipahami, komputasinya efisien, dan memiliki kemampuan untuk mengukur kinerja relatif dari alternatif-alternatif keputusan dalam bentuk matematis yang sederhana.

Secara umum, prosedur TOPSIS mengikuti langkah-langkah sebagai berikut:

a. Membuat matriks keputusan yang ternormalisasi;

b. Membuat matriks keputusan yang ternormalisasi terbobot;

c. Menentukan matriks solusi ideal positif dan matriks solusi ideal negatif;

d. Menentukan jarak antara nilai setiap alternatif dengan matriks solusi ideal positif dan matriks solusi ideal negatif;

Menentukan nilai preferensi untuk setiap alternatif.

\section{METODE}

Pada penelitian ini, yang menjadi obyek penelitian adalah Sekolah Tinggi Agama Hindu Negeri Mpu Kuturan Singaraja. Langkah atau tahapan penelitian ini sebagai berikut.

1. Studi Literatur

Melakukan studi literatur terhadap berbagai referensi yang berkaitan dengan penelitian yang dilakukan. Dalam tahap ini dipelajari literatur tentang konsep Sistem Pendukung Keputusan penerimaan beasiswa Bidikmisi menggunakan kombinasi metode SAW - TOPSIS dalam berbagai sumber berupa buku, artikel dan jurnal
2. Pengumpulan data
Berdasarkan studi literatur data yang diperlukan dalam penelitian ini adalah data

yang meliputi data diri mahasiswa. sedangkan data kelulusan yang digunakan adalah seluruh data mahasiswa yang melamar beasiswa Bidikmisi di STAHN Mpu Kuturan.

3. Penentuan Kriteria

Adapun kriteria yang akan digunakan dalam penilaian calon penerima beasiswa Bidikmisi diantaranya: (1) Penghasilan Ayah Mahasiswa, (2) Penghasilan lbu Mahasiswa, (3) Tanggungan Orang Tua, (4) Rata Rata Nilai Raport, (5) Prestasi Akademik, (6) Tempat Tinggal Mahasiswa, (7) Pendididikan Ayah, (8) Pendidikan Ibu, (9) Luas Tanah, (10) Luas Bangunan. Kreteria yang digunakan dalam penelitian ini diperoleh dari hasil wawancara dengan panitia seleksi penerimaan beasiswa Bidikmisi dan berdasarkan pedoman penyelenggaraan bantuan beasiswa pendidikan Bidikmisi tahun 2017.

\section{Pembobotan}

Pembobotan yang digunakan dalam penelitian ini diperoleh dari hasil wawancara dengan panitia seleksi penerimaan beasiswa Bidikmisi dan berdasarkan pedoman penyelenggaraan bantuan biaya pendidikan Bidikmisi tahun 2017. Adapun pembobotan yang diberikan pada masing-masing kriteria sebagai berikut.

a. Penghasilan Ayah Calon Mahasiswa (C1)

Penghasilan ayah mahasiswa merupakan besarnya penghasilan rata-rata bulanan dari ayah calon penerima beasiswa Bidikmisi. Adapun klasifikasi penghasilan ayah calon mahasiswa adalah seperti pada Tabel 1.

Tabel 1. Klasifikasi penghasilan ayah calon mahasiswa

\begin{tabular}{|r|r|}
\hline $\begin{array}{c}\text { Besarnya Penghasilan Ayah } \\
\text { (Rp.) }\end{array}$ & Bobot \\
\hline $700.000<$ dan $<=1.200 .000$ & 5 \\
\hline $1.200 .000<$ dan $<=1.700 .000$ & 3 \\
\hline $1.700 .00<$ dan $<=2.200 .000$ & 2 \\
\hline $2.200 .000<$ dan $<=3.000 .000$ & 1 \\
\hline
\end{tabular}


b. Penghasilan Ibu Calon Mahasiswa (C2)

Penghasilan Ibu mahasiswa merupakan besarnya penghasilan rata-rata bulanan dari Ibu calon penerima beasiswa Bidikmisi. Adapun klasifikasi penghasilan lbu calon mahasiswa adalah seperti pada Tabel 2.

Tabel 2. Klasifikasi penghasilan ibu calon mahasiswa

\begin{tabular}{|c|c|}
\hline $\begin{array}{c}\text { Besarnya Penghasilan Ayah } \\
\text { (Rp.) }\end{array}$ & Bobot \\
\hline$<=700.000$ & 5 \\
\hline $700.000<$ dan $<=1.200 .000$ & 4 \\
\hline $1.200 .000<$ dan $<=1.700 .000$ & 3 \\
\hline $1.700 .00<$ dan $<=2.200 .000$ & 2 \\
\hline $2.200 .000<$ dan $<=3.000 .000$ & 1 \\
\hline
\end{tabular}

c. Tanggungan Orang Tua (C3)

Tanggungan orang tua merupakan jumlah tanggungan dari orang tua calon penerima beasiswa Bidikmisi. Adapun klasisfikasi tanggungan orang tua adalah seperti pada Tabel 3

Tabel 3. Klasifikasi jumlah tanggungan orang tua

Jumlah Tanggungan Orang Tua $\quad$ Bobot (Rp.)

\begin{tabular}{|r|r|}
\hline 5 & 5 \\
\hline 4 & 4 \\
\hline 3 & 3 \\
\hline 2 & 2 \\
\hline 1 & 1 \\
\hline
\end{tabular}

d. Rata-rata nilai raport (C4)

Rata-rata nilai raport merupakan ratarata nilai raport yang dicapai mahasiswa ketika SMA/SMK. Adapun klasisfikasi Rata rata nilai raport adalah seperti pada Tabel 4.

Tabel 4 Klasifikasi rata-rata nilai raport

\begin{tabular}{|r|r|}
\hline Nilai Rapor & Bobot \\
\hline $91-100$ & \\
\hline $86-90$ & \\
\hline $81-85$ & 4 \\
\hline $75-80$ & 3 \\
\hline $70-74$ & 2 \\
\hline
\end{tabular}

e. Prestasi Akademik (C5)

Prestasi akademik merupakan prestasi yang dicapai calon mahasiswa ketika
SMA/SMK. Adapun klasisfikasi prestasi akademik adalah seperti pada Tabel 5.

Tabel 5 Klasisfikasi prestasi akademik

\begin{tabular}{|r|r|}
\hline Prestasi Akademis & Bobot \\
\hline Rangking 1 & 5 \\
\hline Rangking 2 & 4 \\
\hline Rangking 3 & 3 \\
\hline Rangking 4 & 2 \\
\hline Rangking 5 & 1 \\
\hline
\end{tabular}

f. Tempat tinggal orang tua (C6)

Tempat tinggal orang tua merupakan jenis tempat tinggal dari calon penerima beasiswa Bidikmisi. Adapun klasifikasi tempat tinggal orang tua calon penerima beasiswa Bidikmisi adalah seperti Tabel 6 .

Tabel 6 Klasifikasi tempat tinggal orang tua

\begin{tabular}{|l|r|}
\hline \multicolumn{1}{|c|}{$\begin{array}{c}\text { Tempat tinggal } \\
\text { Orang Tua }\end{array}$} & Bobot \\
\hline Tidak Memiliki & 5 \\
\hline Menumpang & 4 \\
\hline Sewa Bulanan & 3 \\
\hline Sewa Tahunan & 2 \\
\hline Rumah Sendiri & 1 \\
\hline
\end{tabular}

g. Pendidikan terakhir ayah (C7)

Pendidikan ayah merupakan pendidikan terakhir ayah dari colon penerima beasiswa Bidikmisi. Adapun klasisfikasi pendidikan ayah adalah seperti pada Tabel 7

Tabel 7 Klasifikasi Pendidikan Terakhir Ayah

\begin{tabular}{|l|r|}
\hline \multicolumn{1}{|c|}{$\begin{array}{c}\text { Tingkat } \\
\text { pendidikan }\end{array}$} & Bobot \\
\hline Tidak sekolah & 5 \\
\hline SD & 4 \\
\hline SMP & 3 \\
\hline SMA & 2 \\
\hline Diploma/ Strata & 1 \\
\hline
\end{tabular}

h. Pendidikan terakhir ibu (C8)

Pendidikan ibu merupakan pendidikan terakhir ayah dari colon penerima beasiswa Bidikmisi. Adapun klasisfikasi pendidikan ibu adalah seperti pada Tabel 8.

Jurnal Sains dan Teknologi | 120 
Tabel 8 Klasifikasi Pendidikan Terakhir lbu

\begin{tabular}{|l|r|}
\hline \multicolumn{1}{|c|}{$\begin{array}{c}\text { Tingkat } \\
\text { pendidikan }\end{array}$} & Bobot \\
\hline Tidak sekolah & 5 \\
\hline SD & 4 \\
\hline SMP & 3 \\
\hline SMA & 2 \\
\hline Diploma/ Strata & 1 \\
\hline
\end{tabular}

i. Luas tanah (C9)

Luas tanah yang dimaksud adalah luas tanah rumah calon mahasiswa yang dimiliki orang tua. Adapun klasisfikasi luas tanah adalah seperti pada Tabel 9.

Tabel 9 Klasifikasi Luas Tanah

\begin{tabular}{|r|r|}
\hline \multicolumn{1}{|c|}{ Luas Tanah } & Bobot \\
\hline$>200 \mathrm{~m}^{2}$ & 1 \\
\hline $100-200 \mathrm{~m}^{2}$ & 2 \\
\hline $50-99 \mathrm{~m}^{2}$ & 3 \\
\hline$<25-50 \mathrm{~m}^{2}$ & 4 \\
\hline$<25 \mathrm{~m}^{2}$ & 5 \\
\hline
\end{tabular}

j. Luas bangunan (C10)

Luas Bangunan yang dimaksud adalah luas bangunan rumah mahasiswa yang dimiliki. Adapun klasisfikasi luas bangunan adalah seperti pada Tabel 10.

Tabel 10 Klasifikasi Luas Bangunan

\begin{tabular}{|r|r|}
\hline Luas Bangunan & Bobot \\
\hline$>200 \mathrm{~m}^{2}$ & 1 \\
\hline $100-200 \mathrm{~m}^{2}$ & 2 \\
\hline $50-99 \mathrm{~m}^{2}$ & 3 \\
\hline$<25-50 \mathrm{~m}^{2}$ & 4 \\
\hline$<25 \mathrm{~m}^{2}$ & 5 \\
\hline
\end{tabular}

Selain melakukan pembobotan pada klasifikasi masing-masing kriteria. Seluruh kriteria juga diberikan pembobotan secara umum. Nilai bobot untuk setiap kriteria bisa dilihat pada Tabel 11.

Tabel 11 Pembobotan setiap kriteria

\begin{tabular}{|l|l|r|}
\hline Kriteria Bobot & \multicolumn{1}{|c|}{ Kreteria } & Bobot \\
\hline C1 & $\begin{array}{l}\text { Penghasilan } \\
\text { Ayah } \\
\text { Mahasiswa }\end{array}$ & $9 \%$ \\
\hline C2 & $\begin{array}{l}\text { Penghasilan } \\
\text { lbu Mahasiswa }\end{array}$ & $9 \%$ \\
\hline C3 & $\begin{array}{l}\text { Tanggungan } \\
\text { Orang Tua }\end{array}$ \\
\hline
\end{tabular}

\begin{tabular}{|l|l|r|}
\hline Kriteria Bobot & \multicolumn{1}{|c|}{ Kreteria } & Bobot \\
\hline C4 & $\begin{array}{l}\text { Rata rata nilai } \\
\text { raport }\end{array}$ & $18 \%$ \\
\hline C5 & $\begin{array}{l}\text { Prestasi } \\
\text { akademik }\end{array}$ & $17 \%$ \\
\hline C6 & $\begin{array}{l}\text { Tempat tinggal } \\
\text { orang tua }\end{array}$ & $7 \%$ \\
\hline C7 & $\begin{array}{l}\text { Pendidikan } \\
\text { ayah }\end{array}$ & $8 \%$ \\
\hline C8 & Pendidikan lbu & $7 \%$ \\
\hline C9 & Luas Tanah & $9 \%$ \\
\hline C10 & $\begin{array}{l}\text { Luas } \\
\text { Bangunan }\end{array}$ \\
\hline
\end{tabular}

5. Implementasi

Pada tahap ini data yang sudah ditransformasi nantinya akan dimplementasikan ke dalam Sistem Pendukung Keputusan yang dirancang peneliti. Metode yang diimplementasian adalah kombinasi SAW - TOPSIS. Adapun alur / flowchart penerapan metode SAW TOPSIS dalam pengambilan keputusan penentuan penerima beasiswa Bidikmisi seperti pada Gambar.

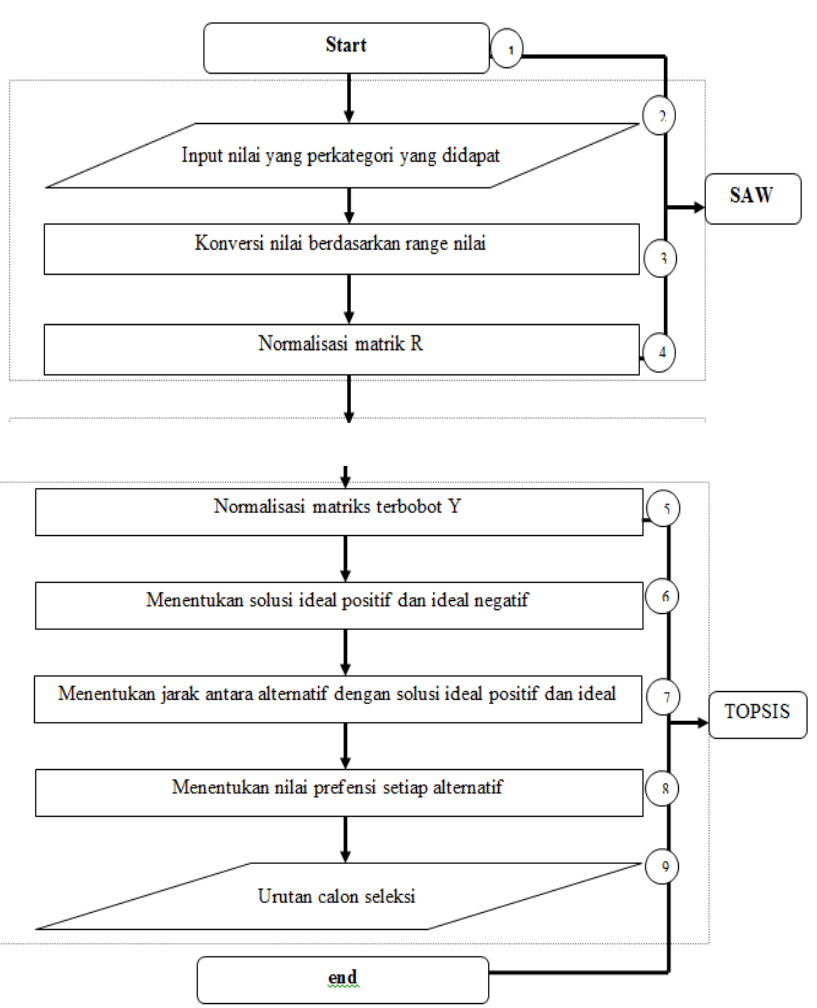

Gambar 1 Implementasi Metode SAW dan TOPSIS

Jurnal Sains dan Teknologi | 121 
Berdasarkan Gambar 1 dapat diperoleh informasi bahawa metode pertama yang digunakan adalah metode SAW hingga memperoleh normalisasi matrik $\mathrm{R}$ kemudian hasilnya dilanjutkan dengan metode TOPSIS untuk perankingan hasil rekomendasi.

\section{Pengujian}

Pengujian akurasi dilakukan dengan membandingkan hasil yang direkomendasikan oleh sistem pendukung keputusan pemberian beasiswa bidikmisi menggunkan metode SAW-TOPSIS dengan hasil dari perhitungan manualnya. Perhitungan manual yang dimaksud adalah hasil dari seluruh nilai yang diperoleh calon mahasiswa pada setiap kriteria.

\section{HASIL DAN PEMBAHASAN}

Penelitian ini dilakukan dengan mengumpulkan data di Sekolah Tinggi Agama Hindu Negeri Mpu Kuturan Singaraja serta melakukan penelitian guna mengimplementasikan program yang dirancang. Data yang diperoleh adalah data kriteria untuk penerimaan beasiswa Bidikmisi dan 30 data calon mahasiswa yang melakukan pendaftaran pada pemberian Bidikmisi pada kampus STAHN Mpu Kuturan Singaraja.

Pada proses implementasi Sistem Pendukung Keputusan menggunakan metode SAW - TOPSIS ada beberapa proses perhitungan guna mendapatkan hasil penilaian menurut metode tersebut. Proses perhitungan untuk no 1 dan 2 menggunakan metode SAW, setelah proses tersebut dilanjutkan menggunakan metode TOPSIS sampai akhir perhitungan. Adapun implementasi SAW-TOPSIS sebagai berikut.

1. Data nilai calon mahasiswa dimasing-masing kriteria disajikan pada Tabel 12.

2. Melakukan proses normalisai nilai menggunakan Persamaan 2 dan Persamaan 3 sehingga membentuk matrik ternomalisasi (R). Hasil normalisasi disajikan pada Tabel 13

3. Proses perhitungan perkalian antara hasil normalisasi (Tabel 13) dengan nilai bobot per-kriteria (Tabel 11). Hasil perkalian disajikan pada Tabel 14. Kemudian melakukan pencarian nilai tertinggi dan nilai terendah dari hasil tersebut. Hasil perkalian disajikan pada Tabel 15.

Tabel 12 Data nilai calon mahasiswa pada setiap kriteria

\begin{tabular}{|c|r|r|r|r|r|r|r|r|r|r|}
\hline \multicolumn{10}{|c|}{ Nilai per-kreteria } \\
\hline Calon & \multicolumn{1}{c|}{ C1 } & \multicolumn{1}{c|}{ C2 } & \multicolumn{1}{c|}{ C3 } & \multicolumn{1}{c|}{ C4 } & C5 & \multicolumn{1}{c|}{ C6 } & \multicolumn{1}{c|}{ C7 } & \multicolumn{1}{c|}{ C8 } & C9 & \multicolumn{1}{c|}{ C10 } \\
\hline 1 & 4 & 5 & 5 & 3 & 0 & 1 & 2 & 4 & 2 & 2 \\
\hline 2 & 5 & 5 & 4 & 2 & 0 & 1 & 4 & 4 & 4 & 4 \\
\hline 3 & 5 & 5 & 3 & 3 & 0 & 1 & 2 & 2 & 1 & 1 \\
\hline$\ldots$ & $\ldots$ & $\ldots$ & $\ldots$ & $\ldots$ & $\ldots$ & $\ldots$ & $\ldots$ & $\ldots$ & $\ldots$ & $\ldots$ \\
\hline 29 & 3 & 4 & 1 & 1 & 0 & 1 & 1 & 1 & 1 & 1 \\
\hline 30 & 5 & 5 & 4 & 2 & 0 & 1 & 3 & 4 & 2 & 4 \\
\hline
\end{tabular}

Tabel 13 Normalisasi nilai calon mahasiswa pada setiap kriteria

\begin{tabular}{|c|c|c|c|c|c|c|c|c|c|c|}
\hline \multicolumn{11}{|c|}{ Nilai per-kreteria } \\
\hline Calon & C1 & $\mathrm{C} 2$ & C3 & $\mathrm{C} 4$ & $\mathrm{C5}$ & C6 & $\mathrm{C7}$ & $\mathrm{C} 8$ & $\mathrm{C9}$ & C10 \\
\hline 1 & 0.8 & 1.0 & 1.0 & 0.8 & 0.0 & 0.3 & 0.4 & 1.0 & 0.5 & 0.5 \\
\hline 2 & 1.0 & 1.0 & 0.8 & 0.5 & 0.0 & 0.3 & 0.8 & 1.0 & 1.0 & 1.0 \\
\hline 3 & 1.0 & 1.0 & 0.6 & 0.8 & 0.0 & 0.3 & 0.4 & 0.5 & 0.3 & 0.3 \\
\hline$\ldots$ & $\ldots$ & $\ldots$ & $\ldots$ & $\ldots$ & . & & & $\ldots$ & $\ldots$ & \\
\hline
\end{tabular}




\begin{tabular}{|c|c|c|r|r|r|r|r|r|r|r|}
\hline \multicolumn{10}{|c|}{ Nilai per-kreteria } \\
\hline Calon & C1 & C2 & C3 & C4 & C5 & C6 & C7 & C8 & C9 & C10 \\
\hline 29 & 0.6 & 0.8 & 0.2 & 0.3 & 0.0 & 0.3 & 0.2 & 0.3 & 0.3 & 0.3 \\
\hline 30 & 1.0 & 1.0 & 0.8 & 0.5 & 0.0 & 0.3 & 0.6 & 1.0 & 0.5 & 1.0 \\
\hline
\end{tabular}

4. Proses pencarian jarak solusi ideal positif dari hasil perhitungan normalisasi $\mathrm{R}$ dan kemudian dilakukan penjumlahan total dari setiap calon yang ada $\left(A^{+}\right)$. Hasil disajikan pada Tabel 16.

5. Proses pencarian jarak solusi ideal negatif dari hasil perhitungan normalisasi $\mathrm{R}$ dan kemudian dilakukan penjumlahan total dari setiap calon yang ada $\left(A^{-}\right)$. Hasil disajikan pada Tabel 17.

6. Proses pencarian nilai preferensi untuk setiap calon yang ada. Proses ini dilakukan pada gambar 3.3 proses no 8. (proses perhitungan menggunakan Metode TOPSIS). Hasil disajikan pada Tabel 18.

Tabel 14 Data perkalian antara tabel ternomalisasi dengan bobot kriteria

\begin{tabular}{|c|c|c|c|c|c|c|c|c|c|c|}
\hline \multicolumn{11}{|c|}{ Nilai per-kreteria } \\
\hline Calon & $\mathrm{C} 1$ & $\mathrm{C} 2$ & C3 & $\mathrm{C} 4$ & C5 & C6 & $\mathrm{C7}$ & $\mathrm{C} 8$ & $\mathrm{C9}$ & C10 \\
\hline 1 & 0.072 & 0.090 & 0.080 & 0.135 & 0.000 & 0.0175 & 0.032 & 0.070 & 0.045 & 0.040 \\
\hline 2 & 0.090 & 0.090 & 0.064 & 0.090 & 0.000 & 0.0175 & 0.064 & 0.070 & 0.090 & 0.080 \\
\hline 3 & 0.090 & 0.090 & 0.048 & 0.135 & 0.000 & 0.0175 & 0.032 & 0.0350 & 0.0225 & 0.020 \\
\hline$\ldots$ & $\cdots$ & & & & & & & & & \\
\hline 29 & 0.054 & 0.072 & 0.016 & 0.045 & 0.000 & 0.0175 & 0.016 & 0.0175 & 0.0225 & 0.020 \\
\hline 30 & 0.090 & 0.090 & 0.064 & 0.090 & 0.000 & 0.0175 & 0.048 & 0.070 & 0.045 & 0.080 \\
\hline
\end{tabular}

Tabel 15 Nilai maksimal dan nilai minimal pada setiap kriteria

\begin{tabular}{|c|c|c|c|c|c|c|c|c|c|c|}
\hline Calon & C1 & C2 & C3 & C4 & C5 & C6 & C7 & C8 & C9 & C10 \\
\hline $\begin{array}{c}\text { nilai } \\
\text { max }\end{array}$ & 0.090 & 0.090 & 0.080 & 0.180 & 0.170 & 0.070 & 0.080 & 0.070 & 0.090 & 0.080 \\
\hline $\begin{array}{c}\text { nilai } \\
\text { min }\end{array}$ & 0.036 & 0.036 & 0.016 & 0.045 & 0.000 & 0.0175 & 0.016 & 0.0175 & 0.0225 & 0.020 \\
\hline
\end{tabular}

Tabel 16 Jarak solusi ideal positif $\left(\mathrm{A}^{+}\right)$dan jumlah total dari setiap calon yang ada.

\begin{tabular}{|c|c|c|c|c|c|c|c|c|c|c|}
\hline \multicolumn{11}{|c|}{ Nilai R di kurangi max } \\
\hline $\begin{array}{l}\text { Cal } \\
\text { on }\end{array}$ & $\mathrm{C} 1$ & $\mathrm{C} 2$ & $\mathrm{C} 3$ & $\mathrm{C} 4$ & C5 & C6 & $\mathrm{C} 7$ & $\mathrm{C} 8$ & C9 & C10 \\
\hline 1 & $\begin{array}{r}0.0003 \\
24\end{array}$ & $\begin{array}{r}0.0000 \\
00\end{array}$ & $\begin{array}{r}0.0000 \\
00\end{array}$ & $\begin{array}{r}0.0020 \\
25\end{array}$ & $\begin{array}{r}0.0289 \\
00\end{array}$ & $\begin{array}{r}0.0027 \\
56\end{array}$ & $\begin{array}{r}0.0023 \\
04\end{array}$ & $\begin{array}{r}0.0000 \\
00\end{array}$ & $\begin{array}{r}0.0020 \\
25\end{array}$ & $\begin{array}{r}0.0016 \\
00\end{array}$ \\
\hline 2 & $\begin{array}{r}0.0000 \\
00\end{array}$ & $\begin{array}{r}0.0000 \\
00\end{array}$ & $\begin{array}{r}0.0002 \\
56\end{array}$ & $\begin{array}{r}0.0081 \\
00\end{array}$ & $\begin{array}{r}0.0289 \\
00\end{array}$ & $\begin{array}{r}0.0027 \\
56\end{array}$ & $\begin{array}{r}0.0002 \\
56\end{array}$ & $\begin{array}{r}0.0000 \\
00\end{array}$ & $\begin{array}{r}0.0000 \\
00\end{array}$ & $\begin{array}{r}0.0000 \\
00\end{array}$ \\
\hline 3 & $\begin{array}{r}0.0000 \\
00 \\
\end{array}$ & $\begin{array}{r}0.0000 \\
00 \\
\end{array}$ & $\begin{array}{r}0.0010 \\
24 \\
\end{array}$ & $\begin{array}{r}0.0020 \\
25 \\
\end{array}$ & $\begin{array}{r}0.0289 \\
00 \\
\end{array}$ & $\begin{array}{r}0.0027 \\
56 \\
\end{array}$ & $\begin{array}{r}0.0023 \\
04 \\
\end{array}$ & $\begin{array}{r}0012 \\
25 \\
\end{array}$ & $\begin{array}{r}0.0045 \\
56 \\
\end{array}$ & $\begin{array}{r}.0036 \\
00 \\
\end{array}$ \\
\hline$\ldots$ & $\ldots$ & $\cdots$ & $\ldots$ & & & $\ldots$ & $\cdots$ & 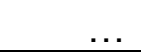 & & \\
\hline 29 & $\begin{array}{r}0.0012 \\
96\end{array}$ & $\begin{array}{r}0.0003 \\
24\end{array}$ & $\begin{array}{r}0.0040 \\
96\end{array}$ & $\begin{array}{r}0.0182 \\
25\end{array}$ & $\begin{array}{r}0.0289 \\
00\end{array}$ & $\begin{array}{r}0.0027 \\
56\end{array}$ & $\begin{array}{r}0.0040 \\
96\end{array}$ & $\begin{array}{r}0.0027 \\
56\end{array}$ & $\begin{array}{r}0.0045 \\
56\end{array}$ & $\begin{array}{r}0.0036 \\
00\end{array}$ \\
\hline 30 & $\begin{array}{r}0.0000 \\
00 \\
\end{array}$ & $\begin{array}{r}0.0000 \\
00 \\
\end{array}$ & $\begin{array}{r}0.0002 \\
56 \\
\end{array}$ & $\begin{array}{r}0.0081 \\
00 \\
\end{array}$ & $\begin{array}{r}0.0289 \\
00 \\
\end{array}$ & $\begin{array}{r}0.0027 \\
56 \\
\end{array}$ & $\begin{array}{r}0.0010 \\
24 \\
\end{array}$ & $\begin{array}{r}0.0000 \\
00 \\
\end{array}$ & $\begin{array}{r}0.0020 \\
25 \\
\end{array}$ & $\begin{array}{r}0.0000 \\
00 \\
\end{array}$ \\
\hline
\end{tabular}


Tabel 17 Jarak solusi ideal positif $(A+)$ dan jumlah total dari setiap calon yang ada

\begin{tabular}{|c|c|c|c|c|c|c|c|c|c|c|}
\hline \multicolumn{11}{|c|}{ Nilai $\mathrm{R}$ di kurangi min } \\
\hline $\begin{array}{l}\text { Cal } \\
\text { on }\end{array}$ & C1 & C2 & C3 & C4 & C5 & C6 & C7 & C8 & C9 & C10 \\
\hline \multirow{2}{*}{1} & 0.0012 & 0.0029 & 0.0040 & 0.0081 & 0.0000 & 0.0000 & 0.0002 & 0.0027 & 0.0005 & 0.0004 \\
\hline & 96 & 16 & 96 & 00 & 00 & 00 & 56 & 56 & 06 & 00 \\
\hline \multirow{2}{*}{2} & 0.0029 & 0.0029 & 0.0023 & 0.0020 & 0.0000 & 0.0000 & 0.0023 & 0.0027 & 0.0045 & 0.0036 \\
\hline & 16 & 16 & 04 & 25 & 00 & 00 & 04 & 56 & 56 & 00 \\
\hline \multirow[b]{3}{*}{3} & 0.0029 & 0.0029 & 0.0010 & 0.0081 & 0.0000 & 0.0000 & 0.0002 & 0.0003 & 0.0000 & 0.0000 \\
\hline & 16 & 16 & 24 & 00 & 00 & 00 & 56 & 06 & 00 & 00 \\
\hline & & & & & & & & & & \\
\hline$\ldots$ & $\ldots$ & & & & & & & & & \\
\hline \multirow{2}{*}{29} & 0.0003 & 0.0012 & 0.0000 & 0.0000 & 0.0000 & 0.0000 & 0.0000 & 0.0000 & 0.0000 & 0.0000 \\
\hline & 24 & 96 & 00 & 00 & 00 & 00 & 00 & 00 & 00 & 00 \\
\hline \multirow{2}{*}{30} & 0.0029 & 0.0029 & 0.0023 & 0.0020 & 0.0000 & 0.0000 & 0.0010 & 0.0027 & 0.0005 & 0.0036 \\
\hline & 16 & 16 & 04 & 25 & 00 & 00 & 24 & 56 & 06 & 00 \\
\hline
\end{tabular}

Tabel 18 Nilai Preferensi Untuk Setiap Calon Yang Ada

\begin{tabular}{|c|c|c|c|}
\hline Calon & Hasil Akhir & Calon & Hasil akhir \\
\hline 1 & 0.5836206483082 & 16 & 0.6142903272903 \\
\hline 2 & 0.5675579790198 & 17 & 0.6575852535751 \\
\hline 3 & 0.6335644257029 & 18 & 0.5687462499144 \\
\hline 4 & 0.6350184147291 & 19 & 0.5541827114436 \\
\hline 5 & 0.3015310825690 & 20 & 0.4764607361695 \\
\hline 6 & 0.5297194831668 & 21 & 0.6746047747208 \\
\hline 7 & 0.6475934111066 & 22 & 0.6506027410404 \\
\hline 8 & 0.5824296926381 & 23 & 0.5593308756538 \\
\hline 9 & 0.5650339798677 & 24 & 0.5986880442057 \\
\hline 10 & 0.3536156978357 & 25 & 0.6084687257066 \\
\hline 11 & 0.7380967631291 & 26 & 0.6306288468657 \\
\hline 12 & 0.6700952197889 & 27 & 0.5557961807833 \\
\hline 13 & 0.5619820094716 & 28 & 0.7004827640789 \\
\hline 14 & 0.5764778067319 & 29 & 0.8684522520114 \\
\hline 15 & 0.7497787645447 & 30 & 0.6070212298068 \\
\hline
\end{tabular}

Berdasarkan Tabel 18 diperoleh informasi bahwa semakin kecil nilai referensi maka calon mahasiswa tersebut paling direkomendasikan oleh sistem untuk diberikan beasiswa bidikmisi. Jadi setelah disortir berdasarkan perolehan hasil akhir pada Tabel 18 diperoleh 10 calon mahasiswa yang direkomendasikan oleh sistem untuk mendapatkan beasiswa bidikmisi pada Tabel 19.
Tabel 19 Rekomendasi dari sistem

\begin{tabular}{|r|r|c|}
\cline { 3 - 3 } Nomor & Calon & Hasil Akhir \\
\hline 1 & 5 & 0.301531083 \\
\hline 2 & 10 & 0.353615698 \\
\hline 3 & 20 & 0.476460736 \\
\hline 4 & 6 & 0.529719483 \\
\hline 5 & 19 & 0.554182711 \\
\hline 6 & 27 & 0.555796181 \\
\hline
\end{tabular}

Jurnal Sains dan Teknologi | 124 


\begin{tabular}{|r|r|r|}
\hline Nomor & Calon & Hasil Akhir \\
\hline 7 & 23 & 0.559330876 \\
\hline 8 & 13 & 0.561982009 \\
\hline 9 & 9 & 0.56503398 \\
\hline 10 & 2 & 0.567557979 \\
\hline
\end{tabular}

Akurasi sistem dicari dengan membandingkan hasil rekomendasi menggunakan metode SAW-TOPSIS dengan hasil perhitungan manual (tanpa metode apapun). Adapun rekomendasi 10 besar perhitungan manual disajikan dalam Tabel 20.

Tabel 20 Rekomendasi Perhitungaan Manual

\begin{tabular}{|r|r|r|}
\hline Nomor & Calon & \multicolumn{1}{c|}{ Hasil Akhir } \\
\hline 1 & 5 & 35 \\
\hline 2 & 2 & 33 \\
\hline 3 & 10 & 31 \\
\hline 4 & 13 & 31 \\
\hline 5 & 19 & 31 \\
\hline 6 & 23 & 31 \\
\hline 7 & 9 & 30 \\
\hline 8 & 18 & 30 \\
\hline 9 & 20 & 30 \\
\hline 10 & 27 & 30 \\
\hline
\end{tabular}

Dengan membandingkan 10 orang rekomendasi dari sistem (metode SAWTOPSIS) terdapat 9 orang yang sama dengan yang diperoleh pada perhitungan tanpa manual. Jadi dapat disimpulkan akurasi sistem pendukung keputusan dengan metode SAW-TOPSIS dalam memberikan rekomendasi beasiswa bidikmisi di STAH Mpu Kuturan sebesar $90 \%$.

\section{SIMPULAN}

Berdasarkan penelitian tersebut diperoleh kesimpulan bahwa sistem pendukung keputusan dengan kombinasi metode SAW-TOPSIS dapat membantu pengambil keputusan dalam pemberian beasiswa bidikmisi di Sekolah Tinggi Agama Hindu (STAH) Mpu Kuturan dengan akurasi sistem sebesar $90 \%$.

\section{DAFTAR PUSTAKA}

\section{Arfida, S. (2013). PENERAPAN METODE TOPSIS DALAM SISTEM PENDUKUNG KEPUTUSAN UNTUK MENENTUKAN PEMENANG LOMBA DESA/KELURAHAN. Jurnal Informatika, 140-148.}

Iriane, G. R., \& Wisnubhadra, I. (2013). ANALISIS PENGGABUNGAN METODE SAW DAN METODE TOPSIS UNTUK MENDUKUNG KEPUTUSAN SELEKSI PENERIMAAN DOSEN. Seminar Nasional Informatika 2013 (SemnasIF 2013), D1-D7.

Kemenristekdikti, S. K. dan K. D. B. (2019). Petunjuk Teknis Pengelolaan Bidikmisi 2019. Jakarta: Ditjen Belmawa Kemenristekdikti.

Kusumadewi, Sri; Hartati, Sri; Harjoko, Agus; Wardoyo, R. (2006). Fuzzy Multi-Attribute Decision Making (Fuzzy MADM). Yogyakarta: Graha IImu.

Mahendra, Gede surya; Subawa, I. G. bendesa. (2019). Perancangan Metode AHP-WASPAS Pada Sistem Pendukung Keputusan Penempatan ATM. Seminar Nasional Pendidikan Teknik Informatika (SENAPATI), 122128. Singaraja: Pendidikan Teknik Informatika.

Subawa, I Gede Bendesa; Wirawan, I Made Agus; Sunarya, I. M. G. (2015). PENGEMBANGAN SISTEM PENDUKUNG KEPUTUSAN PEMILIHAN PEGAWAI TERBAIK MENGGUNAKAN METODE SIMPLE ADDITIVE WEIGHTING (SAW) DI PT TIRTA JAYA ABADI SINGARAJA. Kumpulan Artikel Mahasiswa Pendidikan Teknik Informatika (KARMAPATI), 517-526.

Surya, C. (2015). Sistem Pendukung Keputusan Rekomendasi Penerima Beasiswa Menggunakan Fuzzy Multi Attribut Decision Making (FMADM) dan Simple Additive Weighting (SAW). Jurnal Rekayasa Elektrika, 149-156.

Jurnal Sains dan Teknologi | 125 
Yaqin, A. (2016). Sistem Pendukung Keputusan Kelayakan Pemberian Bidikmisi Dengan Fuzzy Logic (Studi Kasus STMIK AMIKOM Yogyakarta). Cogito Smart Journal, 69-81. 